\title{
Zdekonstruować Metafizykę Arystotelesa
}

Jan Bigaj, Zrozumieć metafizykę. Tom I: Rozszyfrowanie dzieta zwanego 'Metafizyka’'Arystotelesa, Część 1: Bibliofilska kompilacja ijej skutki, Toruń 2004 (ss. 339); Część 2: Elementy sktadowe i ich pochodzenie. Księgi centralne, Toruń 2005 (ss. 516).

MARIAN WESOLY / Poznań /

Mamy tu do czynienia z opracowaniem wyjątkowym, zamaszystym i wyzywającym. Obydwie części I tomu zawierają materiał rozbudowany i przemyślnie ujęty z góry założoną intencją totalnej dekonstrukcji zarówno tekstu, jak i zawartości treściowo-problemowej ksiąg Metafizyki Arystotelesa. Rzecz napisana jest potoczystym i klarownym językiem, nie bez swady i wieszczącego tonu. W części pierwszej rozległe wywody w pięciu rozdziałach dotyczą głównie strony redakcyjnej tekstu. Lektura jest zajmująca, lecz tendencyjna i obrazoburcza w swej wymowie. Dość zacytować następujące stwierdzenia:

„Obecna postać Metafizyki przypomina swoją zawartością kosz z papierami, które ktoś próbował segregować i łączyć w większe całości” (s. 18).

„Najważniejszą konkluzją z naszych rozważań jest, że Metafizyka stanowi nie dzieto autorskie, lecz kompilację redaktorska [podkreślenie Autora]. Ustalenie takiej jej genezy zmusza do radykalnej zmiany metodologii badania jej filozoficznej zawartości” (s. 314). 
Część druga rozprawy jest jeszcze obszerniejsza (czternaście rozdziałów) z wywodami i wnioskami równie destrukcyjnymi, z czego przytoczmy jedynie co następuje:

„Pogląd J. Zürchera, że może to być twórczość Teofrasta, ma więc za sobą poważne racje. Postawiona w tytule części pierwszej dzieła Aristoteles. Werk und Geist, i uzasadniona potem teza, że „obecne Corpus Aristotelicum jest po-arystotelesowskie” (das heutige Corpus Aristotelicum ist nacharistotelisch) stanowi dziś opinio communis i należy do niepodważalnych ustaleń nauki"(s. 506).

Jak dotychczas nikt nie podjął tak przemyślnego tour de force, aby dojść do tak 'niepodważalnych' - w opinii autora - wniosków! Wszelako w swej niepomiarkowanej tendencyjności autor najzwyczajniej się myli, że stanowi to dziś opinio communis; nikt bowiem z nowszych badaczy nie podziela poglądu Zürchera, a krytykowali go za niedorzeczności m.in. P. Siwek i G. Reale (Il concetto di filosofia prima e l'unità della Metafisica di Aristotele, Milano 1994 ${ }^{6}$, s. 450-484). W najnowszym zaś włoskim opracowaniu (M. Zanatta, Aristotele, Metafisica, Introduzione, traduzione e note, testo greco a fronte, vol. 1-2, Milano 2009) krytyka ta powraca: „Stanowisko mącące w pewnych aspektach zawarte jest w dziele Jozefa Zürchera (Aristoteles. Werk), który wywołał tyle wrzawy wśród krytyków, a przyjęto je raczej nieprzychylnie” (zob. ciąg dalszy tej krytyki, S. 154-155).

Ten 10 z kolei włoski przekład Metafizyki z obszernym wstępem i komentarzem (w sumie 2038 stron), a także dwa nowe i gruntowne tłumaczenia niemieckie: Aristoteles, Metaphysik, von Th.A. Szlezàk, Berlin 2003 (ss. 271); Aristoteles, Metaphysik, von G. Zekl, Würzburg 2003 (ss. 595), dają nam miarodajny dziś obraz dzieła Stagiryty, jakże jednak odmienny w metodzie i wnioskach od intencji dociekań Jana Bigaja. W odwrocie bowiem pozostają nierozstrzygalne w zasadzie badania historyczno-genetyczne (entwicklungsgeschichtlich) w stylu W. Jaegera i I. Düringa na rzecz pewnej unitarnej i kontekstowej (Kontextbezogenheit) hermeneutyki w tym zakresie. Albowiem 'zamknięte czytanie' Metafizyki wraz z typowo niemiecką 'Quellenforschung' prowadzi jedynie do rozbicia i wypaczenia tych tekstów. Nowszy stan badań można uzyskać z takich wnikliwych kompendiów: P. Donini, La 'Metafisica' di Aristotele. Introduzione alla lettura, Roma 1995; G. Reale, Guida alla lettura di 'Metafisica' di Aristotele, Roma-Bari 1997.

Ponadto całkowicie nie po myśli Bigaja byłyby interpretacje zawarte w zbiorowym opracowaniu pod wymownym tytułem: Aristotele. Perché la metafisica? Studi su alcuni concetti-chiave della «filosofia prima» aristotelica e sulla struttura dei loro influssi (A. Bausola, G. Reale (cur.), Milano 1994). Szkoda również, że Autor nie wykorzystał fundamentalnej bibliografii: R. Radice, La 'Metafisica' di Aristotele nel XX secolo. Bibliografia ragionata e sistematica, Milano 1996 (wersja angielska: Aristotle's 'Metaphysics'. Annotated Bibliography of the Twentieth-Century Literature, by R. Radice and R. Davies, Leiden-New York-Köln 1997).

W myśl nowszych opracowań nie ma więc takiej tendencji, aby na „organizmie” dogłębnych i inspirujących tekstów Arystotelesa czynić podobne „wiwisekcje”. Postępując konsekwentnie mylnym śladem Zürchera należałoby tak samo rozsiekać i odautoryzować pozostałe pragmatie Arystotelesa, wyszukując w nich redaktorskich kompilacji 
niewiadomego pochodzenia. Wszelako Corpus Aristotelicum jest na tyle jeszcze „tnące filozoficznym życiem”, że nie da się w kawałkach ani tym bardziej w całości pogrzebać.

W lekturze obydwu rozbudowanych Części rozpraw Bigaja zmagamy się z typową petitio principii, czyli założeniem z góry tego, co ma być dopiero wywnioskowane z rozległej argumentacji bez należytego uzasadnienia stopnia pewności tego wywnioskowania. Parafrazując zwięźle stanowisko Autora, można rzecz ująć następująco: „doktryna metafizyczna Arystotelesa jest fikcją, albowiem 1. jako całość była pierwotnie w rozsypce, i 2. została zredagowana z drobnych okruchów przez późniejszych kompilatorów”. Obydwie przesłanki 1. i 2. warunkują się wzajemnie bez możliwości niezależnego ich uzasadnienia. Podstawą jest tu przecież tekst finalny Metafizyki, co do którego nie posiadamy dostatecznych danych historycznych i źródłowych, aby takie przesłanki o fikcyjności w ogóle stawiać. Istnieją natomiast pewne poszlaki, że owa „rozległa pragmateia” była niedokończonym tworem samego Arystotelesa i - podobnie jak Etyka Eudemejska mogła już być zredagowana czy wydana już przez Eudemosa z Rodos, o czym poniżej.

W związku z tym trudno mi uznać za trafny ten radykalny i dalekosiężny projekt dezintegracyjnego rozszyfrowania Metafizyki Arystotelesa. Jak było możliwe, aby na przekór nowszym tendencjom badawczym tak skrajnie potraktować tekst Metafizyki? Niezorientowanemu czytelnikowi o modnej dziś postmodernistycznej orientacji łatwo będzie zawierzyć tej pomysłowej i nośnej dekonstrukcji. Nie wnikając w szczegółową dyskusję, ukażemy jedynie podstawowe wątpliwości i usterki w tym opracowaniu.

\section{Rewelacje ze źródeł - ignotum per ignotius...}

Autor traktuje nader obszernie o mniemanej genezie tekstu Metafizyki, o jego spreparowaniu i kompilacji za sprawą Apellikonta (Cz. 1 rozdz. II-V). Nawet pochlebiał sobie, że wydobył ze źródeł rewelacje, które uszły uwagi takich luminarzy myśli filologicznej jak W. Jaeger, P. Moraux i I. Düring. Chodzi tu głównie o późne i skąpe świadectwa Strabona i Plutarcha, które - zauważmy - w ogóle nie odnoszą się do rzeczonej Metafizyki, a tylko podają pewną wersję przetrwania Corpus Aristotelicum. Oto w dosłownym przekładzie (różniącym się od podanego w rozprawie) te najważniejsze świadectwa:

„Apellikon był bardziej bibliofilem niż filozofem, dlatego starając się naprawić uszkodzenia [rękopisów] przeniósł teksty do nowych odpisów, niezbyt dobrze uzupełniając

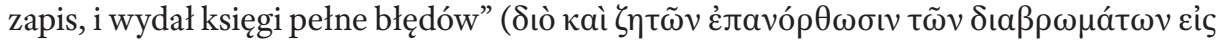


$\pi \lambda \eta ́ p \eta$ тà $\beta ı$ ßía; Strabon, XIII 1, 54 = 66b Düring).

„Powiada się, że po zabraniu jej [biblioteki Apellikona] do Rzymu, gramatyk Tyrannion przygotować miał wiele [ksiąg], a od niego Andronikos z Rodos nabywając odpisy

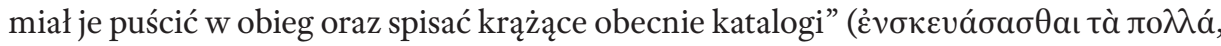

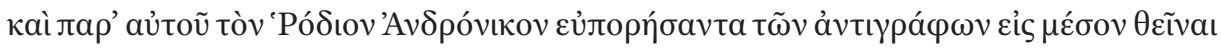

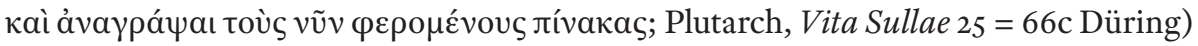


Do tego bardzo ważna i zapewne wiarygodna jest wzmianka u Porfiriusza, który podobnie uporządkował i wydał teksty swego mistrza:

„Tamten zaś [Andronikos Perypatetyk] księgi Arystotelesa i Teofrasta rozdzielił na

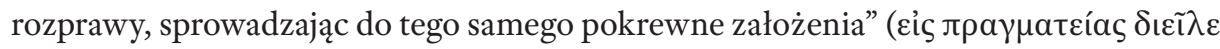

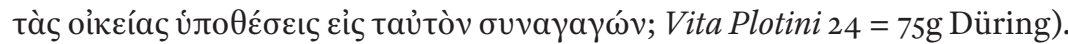

Gdzie tu w ogóle mowa o tzw. księgach Ta mata ta physica? To tylko przypuszczenie (nie potwierdzone w źródłach), że miał je tak nazwać i zredagować Andronikos z Rodos czy nawet wcześniej Apellikon. J. Barnes w swym gruntownym studium („Roman Aristotle”, w: Philosophia Togata, II, Oxford 1997, s. 1-69) stwierdził wprost, ze jego ogólne wnioski co do tego są przygnębiająco sceptyczne: „No text associates Andronicus' name with the creation of the Metaphysics. And something tells against it. The story of Eudemus' edition of Met. doubtless found its justification and explanation in the purported correspondence between Eudemus and Aristotle. I suspect that this correspondence was known to Andronicus, and accepted by him as genuine. In that case Andronicus will have supposed that Eudemus had edited a text of Met., a text which Aristotle himself had prepared; and then Andronicus cannot have claimed to have invented the treatise himself" (s. 62-63).

Jakże więc ową rozległą i wyszukaną argumentację Bigaja ignotum per ignotius, uznać można za rzetelną i trafną, twierdząc, jakoby dzieło Arystotelesa stanowiło wpierw kompilację za sprawą Apellikona, a później zostało spreparowane.


ale bez uzgodnienia. Tego próbował dokonać Tyrannion i Andronikos” (T. 1, Cz.2, s. 122).

Tego przecież w ogóle nie wiemy, czy Apellikon bądź nawet Andronikos, zajmowali się redagowaniem konkretnie owych ksiąg ta meta ta physica!

W grę wchodzi inna wersja przetrwania i zredagowania Corpus Aristotelicum, w szczególności owych „ksiąg pofizycznych”. Zapewne via Rodos za sprawą Eudemosa i jego następców nastąpiło przejęcie znacznej spuścizny Arystotelesa, i w tym też ksiąg „po-fizycznych”. Przytoczmy jedyne w swoim rodzaju świadectwo pochodzące od komentatora Asklepiosa (In Metaph. 4, 4). Nasz dosłowny przekład całkiem różni się od podanego tylko fragmentarycznie przez Bigaja (Cz. 1, s. 123-124).

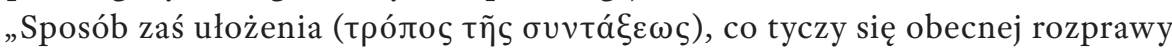

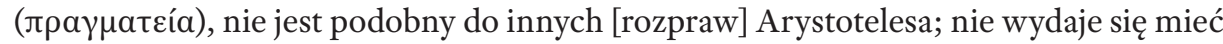

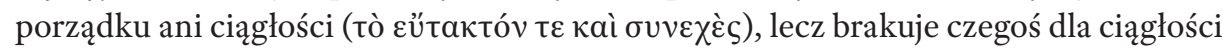

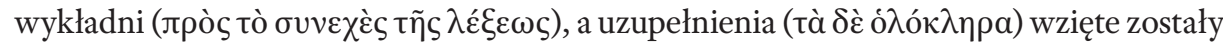
$z$ innych rozpraw i często mówi się o tym samym. W obronie tego występują i pięknie

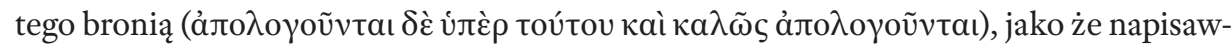
szy obecną rozprawę posłał ją Eudemosowi, swemu przyjacielowi na Rodos, wówczas ten uznał, iż nie jest pięknie, by się stało, udostępnić dla wielu tak rozległą rozprawę

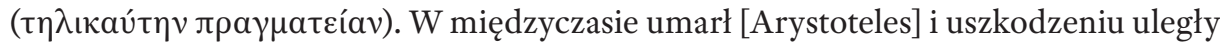
pewne partie tej księgi. Nie odważając się dodawać czegoś od siebie, jego następcy - jako że brakuje im nader wiele z pojętności owego męża (

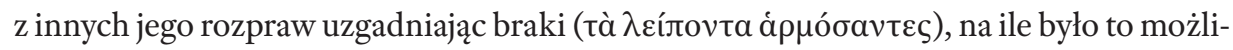




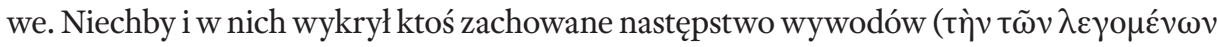

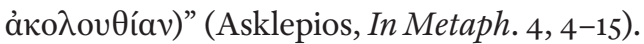

Podług tej wersji, potwierdzonej też przez komentatora Aleksandra, zredagowanie owej rozległej rozprawy (pragmateia) Arystotelesa sięga znacznie wcześniej, do Eudemosa z Rodos (fr. 4 i 124 Wehrli), a nie późniejszego Andronikosa z Rodos, jak bezpodstawnie się podaje (zob. powyżej cytowany J. Barnes). Teksty te bardzo wcześnie mogły znaleźć się w słynnej Bibliotece aleksandryjskiej. Czytamy u Atenajosa, że Laurensius (Larensis) posiadał największe ze wszystkich zasoby biblioteczne, zawierające także filozofów „Arystotelesa i Teofrasta oraz te księgi strzeżone przez Neleusa, od którego je wszystkie zakupując, powiadają, nasz rodzimy król, Ptolemeusz Filadelfos, sprowadził z Aten i Rodos do uroczej Aleksandrii" (Sofiści przy uczcie, 3 a-b).

W związku z tym, moim zdaniem, przekonująco podjął tą wersję H. Reiner w niemieckim artykule z 1954 roku (Bigaj podaje go w swej bibliografii, lecz nie wykorzystuje: T. I, Cz. 2, s. 515), który ukazał się także po angielsku: The Emergence and Original Meaninig of the Name 'Metaphysics' (Graduate Faculty Philosophy Journal 13 (1990), s. 23-53). Uwzględniają też taką wersję nowsi badacze Arystotelesa, jak P. Moraux, G. Reale i E. Berti. Oprócz cytowanego powyżej artykułu J. Barnes’a, odsyłam do nowszych opracowań, gdzie wątpliwości pozostają, ale nie w tak radykalnej i dezintegracyjnej wykładni, jak u Jana Bigaja: L. Brisson, Un si long anonymat, w: La Métaphysique, son histoire, sa critique, ses enjeux, J.-M. Narbonne, L. Longois (ed.), Paris 1999, s. 37-60; hasło «La Métaphysique. Tradition greque», w: Le Dictionnaire des philosophes antiques, Supplément (Paris 2003), s. 224-258.

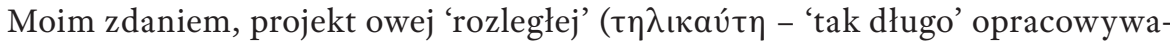
nej), a zredagowanej dopiero pośmiertnie pragmatii, mógł być oryginalnym zamysłem samego Stagiryty w oparciu o jego istotne założenia w księgach logicznych i fizycznych. Podstawowym było tu rozróżnienie pomiędzy proteron physei i proteron pros hemas (cf. Arist., An. Post. I, 2, 71 b 35-72 a 8; Phys. I, 1, 184 a 21-26; 5; 189 a 2-9; Metaph., D 11, 1018 b 29-34; Z 3, 1029 b 3-12; passim), co dało w konsekwencji sformułowanie następczości 'ta physica' - 'ta meta ta physica', podjęte właśnie w późniejszej edycji Corpus Aristotelicum. W każdym razie to ostatnie określenie, uznane w następstwie jako tytuł, odpowiada właściwie oryginalnemu zamysłowi Arystotelesa w jego rozległych dociekaniach problemowych „filozofii pierwszej”.

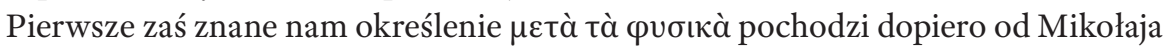
z Damaszku (1 połowa I wieku p.n.e.). Na jednym z manuskryptów księgi Teofrasta o tym

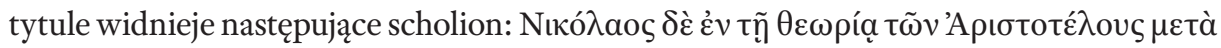

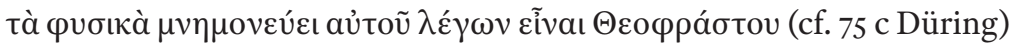

W najnowszej i wzorcowej edycji tzw. Metafizyki Teofrasta (Theophrastus On First Principles (known as his "Metaphysics"): Greek Text and Medieval Arabic Translation, D. Gutas (ed.),Leiden 2010) powyższe zdanie rozumie się następująco: "Nicolaus, though, does mention it in his study of Aristotle's [books that come] after the Physics, saying that it is by Theophrastus". 
Wbrew sugestiom Zürchera i Bigaja wykluczone jest to, aby Teofrast miał wkład w zredagowaniu tzw. Metafizyki Arystotelesa; tenże bowiem był autorem księgi później tak samo zatytułowanej i miał uzasadnione powody, aby w ważnych kwestiach nie zgadzać się ze swoim mistrzem (np. co do zasięgu przedmiotowego pryncypiów oraz przyczyny celowej). Dodajmy, że właściwe rozpoznanie tej księgi Teofrasta jest nader instruktywne przy egzegezie odnośnych ksiąg Stagiryty.

$\mathrm{Z}$ braku danych rzecz pozostaje niejasna i sporna, ale względnie pewne jest to, że określenie meta ta physica odnosiło się pierwotnie do ksiąg „po-fizycznych”, a w tórnie stanowiło wsteczne rzutowanie na ową „rozległą pragmatię” Arystotelesa, jako też na wspomnianą księgę Teofrasta. Arystoteles i Teofrast nie wiedzieli tego, że napisali Metafizykę, tak jak Plotyn nie wiedział, że był autorem Ennead. Arystoteles nie miał też świadomości takiej wykładni, jaką upatrywali w tym późno antyczni, średniowieczni i nowożytni filozofowie. Tu może jest pewne zamieszanie czy przeformułowanie myśli Arystotelesa. Należy wszak rozpoznać adaptacyjny wymiar jego tekstów w zakresie owych ksiąg 'po-fizycznych', nie anulując ich względnej autentyczności, oryginalności czy sensowności problemowej.

\section{Magna etiam animi contentio adhibenda est in explicando, Aristotelem si leges (Cyceron)}

Najpierw ogólnie o (bez)wartości dzieł Arystotelesa. W Akademii ten najzdolniejszy uczeń Platona nie miał uznania u rówieśników i nawet mówiono o nim, że „kopnął swego mistrza, jak świeżo narodzone źrebię własną matkę”. W czasach hellenistycznych przeważały o nim sądy ujemne, a nawet jawne oszczerstwa. W nowożytności Luter, Hobbes i Nietzsche obrzucali go jeszcze większymi obelgami. Czytelnicy bardziej tolerancyjni, otwarci i cierpliwi mogą za Cyceronem stwierdzić, że „należy wielce wytężyć umysł w zrozumieniu lektury Arystotelesa”. W młodości Awicenna czytał czterdzieści razy Metafizykę Arystotelesa, niczego z niej nie rozumiejąc, i dopiero komentarz Abu-Nasr-Farabiego ułatwił mu rozpoznanie sensu i celu tej enigmatycznej książki.

Może wystąpić syndrom Awicenny, jeśli za młodu zaczyna się lekturę Arystotelesa właśnie od Metafizyki. Tak i w wypadku Jana Bigaja, który tyle lat i trudu poświecił, aby w konsekwencji dojść do rewelacyjnego rozszyfrowania tworu zwanego Metafizy$k a$, że jest to niespójny tematycznie, przypadkowy zbiór tekstów, zredagowany z drobnych odruchów na podstawie uprzednich ciągłych przeróbek. Oprócz rewelacyjnego odczytania źródeł, Bigaj starał się rozdrobnić sekwencje tekstów tzw. Metafizyki, ukazać w nich luki, ubytki, usterki, niekonsekwencje, redaktorskie poprawki, doklejone wstaw$\mathrm{ki}$, interpolacje itp.

Niezależnie od spornej kwestii pochodzenia i przetrwania tekstów tzw. Metafizyki, stan finalny jej ksiąg ma niewątpliwe zaplecze problemowe w logice i fizyce Arystotelesa, a te dziedziny stały się przedmiotem dociekań i adaptacyjnego namysłu wybitnych uczonych. Za sprawą Jana Łukasiewicza, jak wiadomo, nastąpiło nowoczesne rozpoznanie 
oryginalności i głębi myśli logicznej Arystotelesa. Z kolei w dziedzinie przyrodniczej tacy laureaci Nobla, jak M. Delbrück (1969) i I. Prigogine (1977), gotowi byli podzielić się tą nagrodą z Arystotelesem, który ich w znacznym stopniu inspirował. Wspominam o tym, aby podkreślić, że studiowanie Arystotelesa nie należy zaczynać od ksiąg Metafi$z y k i$, lecz od dwóch dziedzin wyjściowych wnikliwie przezeń rozpracowanych: logicznej (analitycznej) i fizycznej (przyrodniczej), które stanowią w istocie teoretyczne zaplecze dla zrozumienia jego wysoce sproblematyzowanych, aporetycznych i wielowątkowych rozważań w księgach „po-fizycznych”. Zrozumienie tych często lapidarnych i niejasnych wywodów wymaga kontekstowego sięgania do wielu miejsc w Corpus, które w pewnym stopniu wzajemnie się uzasadniają.

Księgi „po-fizyczne” nie zostały napisane w jednym systematyzującym ciągu, lecz nie należy z góry zakładać, że możliwe do stwierdzenia różnice chronologiczne prowadziły do istotnych różnic doktrynalnych. Były to raczej przeformułowania czy modyfikacje odautorskie, stąd kontekstowe czytanie Arystotelesa umożliwia nam wieloaspektowe i względne spójne rozszyfrowanie jego wywodów. Krótko mówiąc, księgi „po-fizyczne” są projektującą „nadbudową” nad dociekaniami w traktatach logicznych i fizycznych. Zespół zredagowanej później Metafizyki to nie są teksty w pełni autonomiczne czy autarktyczne. Przypisanie zaś całego w nich splotu odnośników i wstawek rzekomym kompilatorom, gdy nie ma tego potwierdzenia w źródłach - stanowi po prostu błąd ignotumperignotius.

Dziedzina, w której Stagiryta pozostaje wiekopomnym twórcą, to jego analityka i apodejktyka z Analityk oraz argumentacja dialektyczna z Topik. Ostatnio I. Bell w swej instruktywnej rozprawie (Metaphysics as an Aristotelian Science, Sankt Augustin 2004) zasadnie wykazał, że Metafizyka Arystotelesa "represents an attempt to construct a science of being along the rigorous lines proposed in the Posterior Analytics [...] Aristotle ask us to think of the inquiry into the formal principles of reality after the same model as we would inquiry into mathematical or physical principles and properties" (s. 241).

To właśnie próba kontekstowego czytania greckiego filozofa. Ponadto, aby czytać i rozumieć metodologiczne wątki w Metafizyce Arystotelesa, należy właściwie rozpoznać dialektykę i aporetykę z jego Topik, czyli strategię rozstrzygania problemów filozoficznych, na co trafnie wskazują tacy badacze, jak E. Berti, C. Rossitto i T. Irwin (zob. T. Irwin, Aristotle's First Principles, Oxford 1988 [przekład włoski: Milano 1996] oraz jego interpretację - „strong dialectic”, s. 476 n.).

Drugie jednakowo ważne zaplecze ksiąg „po-fizycznych” stanowią pojęcia i założenia właśnie w zakresie physis. Albowiem wspólne dla fizyki i filozofii pierwszej, oprócz metody diaporetycznej, było badanie zasad, przyczyn i elementów wszechrzeczy. Wskazywało już na to wielu badaczy, w szczególności zaś T. Buchheim (The Functions of the Concept of Physis in Aristotle's Metaphysics, OSAPh 20 (2001), s. 201-234).

Tak więc księgi Metafizyki są wytworem wtórnym, na bazie tamtych, wytworem wysoce sproblematyzowanym, diaporetycznym i otwartym na dalsze dociekania. Są to wprawdzie wywody (logoi) niejednolite i wielowątkowe, ale trudno je uznać za „niespójną tematycznie całość”. Wiadomo, że tytuł Metafizyki (podobnie jak Organonu) nie jest 
Arystotelesowy, ale nie można mu odmówić pewnej zasadności merytorycznej, albowiem owo projektujące dociekanie ‘filozofii pierwszej' (jeśli nią nie jest 'fizyka') stanowi jeden z ważniejszych postulatów badawczych greckiego filozofa. Wywodów w tym zakresie nie można uznać za bezprzedmiotowe czy wręcz „fikcyjne”, gdyż nie brak im kontekstowego problematyzowania i względnej konsystencji. W każdym razie dla egzegetów po dzień dzisiejszy stanowią przedmiot namysłu i nie lada inspirację filozoficzną.

Arystoteles wykonał ogromny trud badawczy w dziedzinie przyrodniczej (fizycznej, kosmologicznej, meteorologicznej, psychologicznej, biologicznej i zoologicznej), toteż nie mógł na tej podstawie nie stawiać pytań i dociekać poznania wyższego rzędu, właśnie wiedzy czy mądrości nadrzędnej (filozofii pierwszej), zarówno w sensie metodologicznym, jak i przedmiotowym. Miał przy tym świadomość, że oddzielnej kompetencji wymaga szukanie wiedzy i jej metody, a niełatwo jest uchwycić nawet jedną z nich (cf. Arist. Metaph. a 3).

Rzeczywistością zaś szczególnie przezeń badaną były ousiai (gatunki i rodzaje), czyli rzeczy i ciała naturalne o swoistych własnościach ogólnych (kategorie ilości, jakości, relacji itd.). Problematyka substancji zmysłowej była przedmiotem jego wnikliwych dociekań diaporetycznych w centralnych księgach po-fizycznych (E, Z, H, $\Theta, L$ ), stąd niezbywalna zbieżność fizyki i metafizyki. Tak pojęta 'filozofia pierwsza' była metodologicznie pochodną fizyki z ukierunkowaniem na substancjalizm (ousiologia, hylemorfizm). Arystoteles bowiem pojmował ogólnie physis jako ousiai $\mathrm{w}$ sensie dynamicznym podług swych czterech przyczyn (materii, formy, źródła ruchu i celu), a zatem jako spełnianie się zmysłowych konkretów.

Niestety odnoszę wrażenie, że Autor nie uznaje za istotną, oryginalną i wiążącą teoretycznie żadnej koncepcji greckiego filozofa; dyskredytuje bowiem i przeinacza jego nader ważne pojęcie episteme i odmawia nawet oryginalności hylemorfizmowi Arystotelesa - to ponoć twór Szkoły. Wszelako na bazie swej teorii predykacji i apodejktyki opracował Stagiryta wnikliwie swą doniosłą koncepcję wiedzy naukowej (episte$m e) \mathrm{w}$ różnych zakresach. Episteme to hexis apodeiktike, czyli „dyspozycja do dowodzenia i wyjaśniania”, nie w sensie potocznym, ale ściśle przezeń sformułowanym w Analitykach.

Tymczasem zdaniem Jana Bigaja, filozofia dla Arystotelesa nie jest episteme, lecz cechą człowieka, oznaczając wybitną mądrość (zob. Arist., EN, VI, 3, gdzie sophia to przecież połączenie episteme i nous). Sprowadzenie zaś episteme do czystej (mądrościowej) „sprawności” (umiejętności, postawy filozofa), bez odniesień do dziedzin przedmiotowych, które z takim oddaniem on uprawiał, jest niezrozumieniem jego konkretnych dokonań i świadomości w zakresie filozofii nauki. Kosztem dyskredytacji dociekanej przez Arystotelesa episteme, Jan Bigaj zdobywa się na niebywałą deformację translatorską niniejszego tekstu:

Możliwe jest badanie tylko orzecznikowości samej, to znaczy tylko tego, co zwiazane ze stosowaniem stowa «być». Bytby to sposób podejścia catkiem odmienny od tych, gdzie uwzględnia się orzecznikowość jedynie w ograniczonym zakresie. Nie ma dotąd wyspecjalizowanych badań nad orzekaniem w ogóle. Czyni się to tylko po części 
i okazjonalnie w niektórych operacjach, np. matematycznych. [pokreślenie Autora, T. 1, cz. 2, s. 216].

Żaden $\mathrm{z}$ dotychczasowych przekładów nie czynił tego miejsca tak niezrozumiałym.

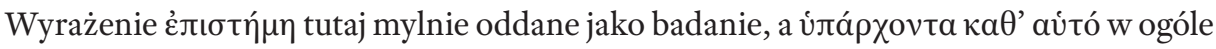
nie znaczy - to „co związane ze stosowaniem słowa «być» [?]. Jakże owa „orzecznikowość sama” przejawiać się ma okazjonalnie w operacjach matematycznych? Stagiryta postuluje badanie zasad, przyczyn i elementów w odniesieniu do tò ô $v$ ก̃ ôv. Jakże więc chodzić może o badanie owych zasad, przyczyn i elementów w odniesieniu do „orzecznikowości samej” [?!]. Typy predykatów (kategorie) to wyrażenia języka, ale z odniesieniem przedmiotowym do rzeczy i ich własności. Na temat semantyki i realizmu poznawczego Stagiryty sporo można się dowiedzieć z nowszej literatury przedmiotu. Dociekanie definicyjnej istoty opiera się na właściwościach składniowych języka, ale winno mieć odniesienie przedmiotowe.

Obniżając wartość i autentyczność tekstów Arystotelesa Autor z niejakim przekąsem czy ironią wyraża się o jego słownictwie aporetycznym i aporetyce „metafizycznej”. Traktowanie wywodów Arystotelesa jako czysto „słownikowych” można uznać jedynie cum grano salis. Filozof grecki bada bowiem nie pojedyncze znaczenia słów, a tylko stosuje różne dystynkcje w aspekcie predykacji (kath’ hauto - kata symbebekos), które są dlań wiążące i rozstrzygające w dalszych analizach pojęciowych.

Wbrew temu, co czytamy w Części 2 rozprawy Bigaja wokół ksiąg centralnych Metafizyki, najnowsze studia i przekłady ukazują nam nie lada poziom i konstrukcję argumentacyjną, doniosłą też dla dzisiejszej filozofii. Oto tytuły ważniejszych opracowań:

M. Frede, G. Patzig, Aristoteles, Metaphysik Z, I-II, München 1988 (przekład włoski: Milano 2001);

D. Bostock, Aristotle: Metaphysics Books Z and H, Oxford 1994;

M. Burnyeat, A map of Metaphysics Zeta, Pittsburgh 2001 (cf. M. L. Gill, "Myles Burnyeat's Map of Metaphysics Zeta”, PQ (2005), s. 114-121);

G. Galluzzo, M. Mariani, Aristotle's Metaphysics Book Z: The Contemporary Debate, Pisa 2006;

S. Makin, Aristotle, Metaphysics. Book $\Theta$, Oxford 2006;

W. Detel, Aristoteles Metaphysik Bücher VII und VIII, Frankfurt am Main 2009.

Wprawdzie nie jestem skłonny nazywać Arystotelesa „metafizykiem”, ani tym bardziej anachronicznie Parmenidesa czy Platona, to jednak można - historycznie rzecz biorąc - tak rozumieć jego „metafizykę”. Otóż nie jest ona „teologią” racjonalną w myśl neoplatońskich antycznych i średniowiecznych komentatorów. Nie jest też „ontologią”, jak chcieli tego filozofowie nowożytni, od Suáreza do Natorpa. Nie jest ona tym bardziej „onto-teologią”, jak za Brentano i Heideggerem rozpracowują ją liczni rzecznicy takiego podejścia. Metafizykę Arystotelesa pojmuję jako dociekanie pryncypiów, zaistniałe już w Akademii ateńskiej (Platon, Speuzyp, Ksenokrates), jak ukazali to badacze ze „szkoły” w Tübingen (Prinzipienlehre), a także E. Berti z Padwy, i jak doszedł do tego niezależnie uczony amerykański T. Irwin (Aristotle’s First Principles). 